\title{
Maytenus guianensis Klotzsch Ex Reissek (Celastraceae): ethnopharmacological aspects and isolated constituents
}

\author{
Maytenus guianensis Klotzsch Ex Reissek (Celastraceae): aspectos etnofarmacológicos e constituintes isolados
}

Renato Abreu Lima ${ }^{1}$, Dionatas Ulises Meneguetti ${ }^{2}$, Fernanda Bay Hurtado ${ }^{3}$, Júlio Linhares Militão ${ }^{3}$, Valdir Alves Facundo 3

${ }^{1}$ Doutorando em Biodiversidade e Biotecnologia pela Universidade Federal do Amazonas, Brasil renatoabreu07@hotmail.com

${ }^{2}$ Universidade Federal do Acre, UFAC, Rio Branco, Acre, Brasil

${ }^{3}$ Universidade Federal de Rondônia, UNIR, Presidente Médici, Rondônia, Brasil

\begin{abstract}
This study consists of a literature review on the traditional use of the medicinal plant Maytenus guianensis, which was carried out using the databases: LILACS, SciELO, and PubMed. M. guianensis is popularly known as xixuá and occurs throughout the tropical and subtropical band of the world. In Brazil, its leaves, bark, and roots are used as tea or macerated for the treatment of inflammation and infections in general. It is also popularly used to treat rheumatism and worm infections. These medicinal uses which have experimental support seem to be mainly associated with the presence of triterpenes.
\end{abstract} Keywords: Maytenys guianensis; xixuá; triterpenes

\section{Resumo}

O presente trabalho constitui-se de uma revisão bibliográfica sobre o uso tradicional da planta medicinal Maytenus guianensis na qual foram utilizadas as bases de dados: LILACS, SciELO e PubMed. M. guianensis é conhecida popularmente como xixuá e ocorre em toda a faixa tropical e subtropical do mundo. No Brasil, suas folhas, cascas e raízes são utilizadas em forma de chá ou maceração no tratamento de inflamações e infecções em geral. Outras doenças e condições em que acha emprego popular incluem reumatismo e verminoses. Esses usos medicinais que têm apoio experimental parecem associados principalmente à presença de triterpenos.

Palavras-chave: Maytenys guianensis; xixuá; triterpenos 


\section{INTRODUCTION}

This work consisted in a bibliographic qualitative study, descriptive and exploratory, about action and damage caused by Maytenus guianensis, from electronic search databases, as well as the Google Scholar access, Scientific Electronic, Library Online (SciELO) and Capes Journal, have been evaluated by scientific articles means, dissertations, theses, books and monographs the years 1995-2015 in Portuguese, English and Spanish, selecting those that brought relevant scientific single document information on the specie $M$. guianensis.

According to Rodrigues (2007), the literature search is a search mode in which scientific knowledge and recovered by a problem in which the exploratory research and provides greater depth with the problem, going through lifting bibliographies or interviews, and a qualitative research approach is one that describes and that the information can not be described in numbers.

According to Tozoni-Reis (2010), all the search modes require literature review [...], but only the bibliographical research is the literature data collection field. To Lima; Mioto, (2007), the literature is more labor intensive, because demand more attention to the work is not affected.

\section{SYNONYMY}

Chichuá, xixuá, chuchahuasi, chucchu huashu, chuchuasi, chuchasha, and tonipulmon (BORRÁS, 2003; DUCKE; VASQUEZ, 1994; REVILLA, 2002).

\section{USED PARTS}

The leaves, roots, and barks are mainly used, but all parts of $\mathrm{M}$. guianensis may be used in traditional medicine. This plant also has nutritional value and it is used in seasonings (REVILLA, 2002). In addition, the red powder of the root bark of this plant is used by indigenous people (SOUSA, 1986). Its roots and stems are also used to treat infections and inflammations in general (BORRÁS, 2003).

\section{GEOGRAPHIC DISTRIBUTION}

In the Amazon, there are numerous species of plants with medicinal properties (OSAKADA, 2009), including the Celastraceae family, which consists of 98 genera and approximately 1,264 species (FONSECA et al., 2007, LORENZi; MATOS, 2008; OLIVEIRA et al., 2012), distributed in different parts of the world, particularly in tropical and subtropical regions, including North Africa, South America and Asia (SPIVEY; WESTON; WOODHEAD, 2002; DUARTE et al., 2010; HURTADO, 2013; MOHAMED; PERWEZ, 2014).

Maytenus is the largest and most diverse genus of the Celastraceae family and it is included in the Celastroideae subfamily, Oxphylla section, which is restricted to South America (CARVALHO-OKANO; LEITÃO-FILHO, 2005). This genus has about 200 tropical species; among these, 76 species and 14 varieties are found in Brazil, mainly in the South region (NEGRI; POSSAMAI; NAKAHIMA, 2009). Specimens of this genus are found in the Amazon forest, Atlantic forest, Cerrado (Brazilian savanna), Restinga (forest on sandbank along the coastal), Caatinga, and campo rupestre (rocky field). Maytenus guyanensis is an endemic tree of solid land, found in some areas of the Amazon forest, mainly in Peru, Ecuador and Colombia (BORRÁS, 2003; DUCKE; VASQUEZ, 1994; REVILLA, 2002).

\section{BOTANICAL DESCRIPTION OF THE PLANT}

The leaf of M. guyanensis is oblong-lanceolate or elliptical, entire, acuminate, coriaceous, and glossy on the upper surface, with $10-20 \mathrm{~cm}$ length and $3-4 \mathrm{~cm}$ width, cartacea, prominent central and inconspicuous secondary vein on both surfaces; this plant has apex acuminate to cuspidate with petiole of $4 \mathrm{~mm}$ width, inflorescence axillary, numerous minute pentamerous flowers, colorful calyx with deciduous teeth and white obovate petals, its fruit is an ovoid capsule, with oblong seeds with white arils (REVILLA, 2001; 2002). The stem is cylindrical with fluted base. It has yellowish brown furrowed rhytidome; detachment in papyraceous plates (RIBEIRO et al., 2009).

\section{MICROSCOPIC CHARACTERISTICS}

The structure of the secondary growth root has distinct growth layers, bounded by marginal parenchyma bands, distributed at regular intervals. It has vessels of diffuse distribution, uniform, circular 
section, with a thin wall; an average of $2.44 \mu \mathrm{m}$ thick, solitary pores, and tangential diameter of 20 - 29 micrometers (PRATA, 2007). Although METCALFE; CHALK (1957) mentions that the vessels of the roots of the Celastraceae family often contain tylose, it was not observed in the root vessels of M. guianensis. Vessel elements with and without appendages were found, such appendages were present at both ends. The intervessel pits are alternate and bordered; the axial parenchyma is apotracheal in transversal section and in bands (PRATA, 2007).

The periderm of the species belonging to the Celastraceae family originates in the subepidermal layers. The cells of this layer suffer periclinal divisions, producing phellogen cells towards the periphery, and phelloderm towards inward. This behavior corroborates the observations of Solereder (1908) and Metcalfe; Chalk (1957) to Maytenus genus. The lenticels have filling tissue composed of about 20 layers of juxtaposed cells (GLÓRIA; GUERREIRO, 2006).

According to Glória; Guerreiro (2016), because of this continuity of intercellular spaces and the internal tissues of the axial organ, it is supposed that the function of the lenticels is related to the exchange of gasses. The developed periderm consists of a relatively thick phellem composed about 30 layers of tabular cells naturally colored with two color patterns: reddish brown and dark brown. Sequentially, it is observed the phellogen and a phelloderm with 4 rows of cells with natural yellowish brown color.

As described by Glória; Guerreiro (2006), phellem cells are typically devoid of visible content, however in some cases, it is possible to observe the accumulation of resin or phenolic compounds. In cross-section, the phellogen cells are rectangular, radially flattened with a compact arrangement, which is observed in M. guianensis.

The phelloderm consists of active parenchyma cells, similar to the cortical parenchyma and may be distinguished from the other cells according to their alignment with the phellogen cells. The cortex has cells with a rounded shape, surrounded internally by fibers and several stone cells (PRATA, 2007).

\section{FOREMOST CHEMICAL COMPONENTS}

According to Lima et al. (1969), who were the first researchers to devote themselves to Maytenus spp. phytochemical studies, this species presented several phytochemical groups; the most prominent were terpenoids, alkaloids, tannins, macrolides, and flavonoids, among others (COIMBRA, DA SILVA, 1958; CARLINI; FROCHTENGARTEN, 1988; ALONSO, 1998; SANTOS-OLIVEIRA et al., 2009; SIMÕES, 2007; ESTEVAM et al., 2009). The presence of these groups was later confirmed, and their therapeutic potential is well known.

Macari; Portela; Pohlit (2006) performed a chemical study on the bark ethanolic extract of M. guianensis, resulting in the isolation of the flavonoid 4-methyl epigallocatechin; and finally, Hurtado (2013) conducted a phytochemical study on its inner bark, which resulted in the isolation of six pentacyclic triterpenes: 3-oxofriedelane, 3 3 -hydroxyfriedelane, 3-oxo-16 $\beta$-hydroxyfriedelane, 3-oxo-29-hydroxyfriedelane, tingenone and tingenine $\mathrm{B}$ (Figure 1).

The heartwood (PINHEIRO, 1990), bark (SOUSA et al., 1986; MACARI; PORTELA; POHLIT, 2006; LIMA; VARGAS; POHLIT, 2010), and inner bark (HURTADO, 2013) of M. guianensis have been already studied. In his dissertation Pinheiro (1990) conducted a study on the heartwood ethanolic extract of this species, resulting in the isolation of the following secondary metabolites: dulcitol, N,N-dimethylserine, $\beta$-sitosterol, $\beta$-sitostenone, 3,7-dioxofriedelane, proanthocyanidin A, and 4'-O-methyl-(-) epigallocatechin (Figure 2). Sousa et al. (1986) carried out a study on the root ethanolic extract and they isolated the wilfordine and evonine sesquiterpene alkaloids.

Phytochemical studies on leaves, stem barks, and roots of $\mathrm{M}$. guianensis led to the isolation and identification of the following terpenoids: five friedelane (friedeline, friedelol, 16 $\beta$-friedeline, 29-hydroxifriedeline and 3,7-friedelodione), one $\beta$-amerine oleanane, one $\beta$-amerine ursane, and three friedo-nor-oleanane (quinine-methides) (tingenone, 22-hydroxy-tingenone and 22-hydroxy-pristimerine). In addition, two steroids ( $\beta$-sitosterol and sitostenone), one sesquiterpene alkaloid (N,N-dimethylserine) (SOUSA et al., 1986; FACUNDO et al., 2015), and one flavonoid (4-methyl-epigalocatequine (MACARI et al., 2004) were also identified. 


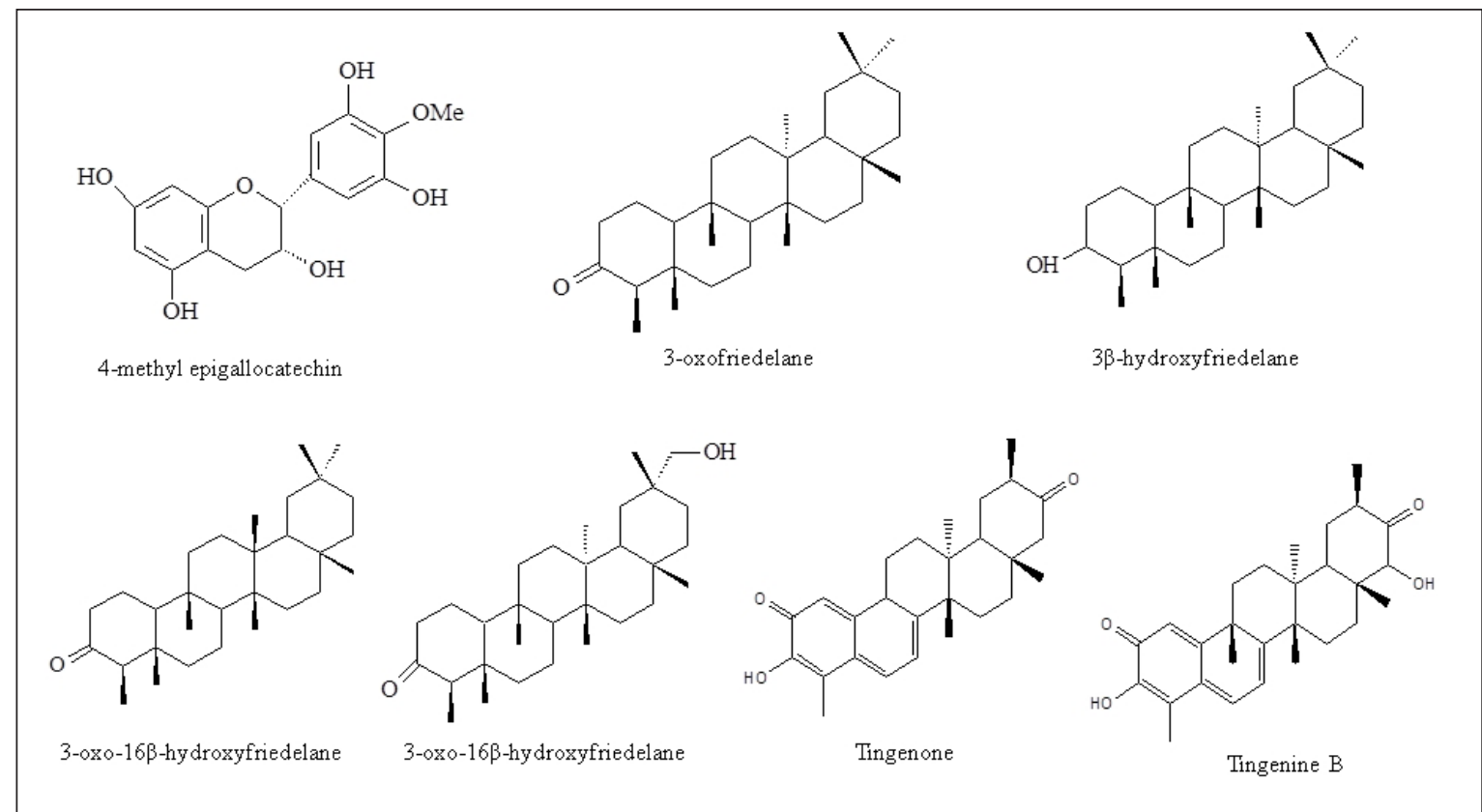

Figure 1 - Molecular structures of secondary metabolites isolated from the ethanol extract of the variety and acetone extract of inner bark.

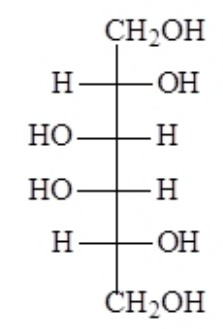

Dulcitol

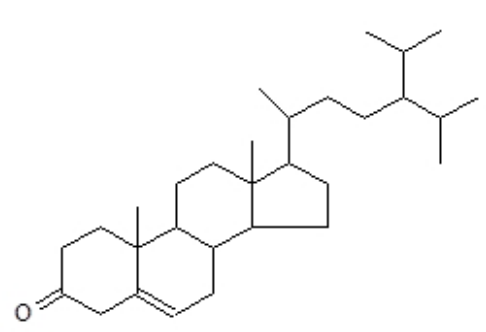

B-Sitostenone<smiles>COc1c(O)cc(C2Oc3cc(O)cc(O)c3C[C@H]2O)cc1O</smiles>

4'-O-methyl-(-)epigallocatechin<smiles>CN(C)C(CO)C(=O)O</smiles>

$\mathrm{N}, \mathrm{N}$-dimethylserine<smiles>CC1CCCCC12CCC(O)CC2C</smiles>

$\beta$-Sitosterol<smiles></smiles>

3,7-Diox ofriedelane<smiles>COc1cc(O)c2c(c1)O[C@H](c1cc(O)c(OC)c(O)c1)C(O)[C@@H]2c1c(O)cc(O)c2c1O[C@H](c1cc(O)c(O)c(O)c1)[C@H](O)C2</smiles>

Proanthocyanidin A

Figure 2 - Molecular structures of secondary metabolites isolated of heartwood ethanolic extract. 


\section{MEDICINAL USES}

The red powder of the root bark of $\mathrm{M}$. guianensis is used by indigenous people as an alcoholic infusion as a general tonic, for the treatment of rheumatism, as contraceptive and aphrodisiac. For the topical use, it is used as an antitumor agent for skin cancer, as well as for the treatment of wounds (DA SILVA, 1990).

Its roots and stems are also used as an analgesic, anti-inflammatory, aphrodisiac, muscle relaxant, anti-rheumatic and anti-diarrheal. This species is also indicated for the treatment of arthritis, sexual impotence, colds, bronchitis, hemorrhoids, worm infections, lumbago, external ulcers, and gynecological purposes (BORRÁS, 2003). As a cosmetic it is used in skin rashes and to prevent the skin cancer (REVILLA, 2002).

As tincture it is used as a muscle relaxant, to treat arthritis and rheumatism; as decoction a part of the bark is used (about 2 to 5 centimeters in 2 liters of water); to treat arthritis and rheumatism it was reported a cup (coffee) three times a day for a week (BORRÁS, 2003). The decoction of the branches is considered a stimulant and tonic (DUCKE; VASQUEZ, 1994). Moreover, it is used for antiparasitic action (MACARI; PORTELA; POHLIT, 2006), demonstrating a great ethnopharmacological potential to be explored.

\section{MEDICINAL PROPERTIES SUPPORTED BY SCIENTIFIC EVIDENCE}

In recent years, there has been a significant increase in the interest in plants belonging to the Maytenus genus, especially in Brazil, which has nearly $40 \%$ of all known species (CARVALHO-OKANO; LEITÃO-FILHO, 2004), which occur in the North (Acre, Amazonas, Amapá, Pará, Rondônia, Roraima), Northeast (Alagoas, Bahia, Ceará, Maranhão, Paraíba, Pernambuco, Piauí, Rio Grande do Norte, Sergipe), Midwest (Distrito Federal, Goiás, Mato Grosso do Sul, Mato Grosso), Southeast (Espírito Santo, Minas Gerais, Rio de Janeiro, São Paulo), and South region of this country (Paraná, Rio Grande do Sul, Santa Catarina), with some species used in traditional medicine.

Maia et al. (2009) identified by the platelet aggregation test that the dry extract of M. guianensis bark showed mediated inhibition of aggregation of $26 \%$ at a concentration of $200 / \mathrm{ml}-1$ and $77 \%$ at a concentration of $400 \mu \mathrm{g} / \mathrm{mL}-1$, making possible the use of this species for pharmacological purposes.

\section{ANTI-LEISHMANIA ACTIVITY}

Macedo et al. (2015) reported that an isolated triterpene of $\mathrm{M}$. guianensis incorporated into microparticles in solution proved to be highly toxic to the parasites, according to the IC-50 value. When it was encapsulated in the microparticles, it maintained its activity anti-leishmania, but in a more attenuated way and sustained over time, suggesting that the developed microparticles have the potential of a modified release system for subsequent intracellular delivery of the triterpene to eliminate amastigotes.

\section{ANTIMALARIAL ACTIVITY}

The M. guianensis extracts showed a good anti-P. falciparum activity in HRPII trials and the most active result was for EAMG with IC50 of 190.37 ๆ. $\mathrm{mL}-1$, and the less active result for EHMG

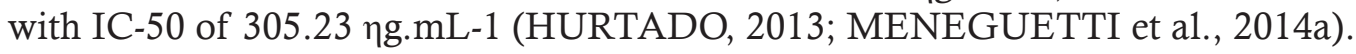

\section{ANTIOXIDANT ACTIVITY}

Bay-Hurtado et al. (2015) evaluated the antioxidant activity of the "on bark" of M. guianensis for concentrations of $10,50,100,150$ and $250 \mu \mathrm{g} . \mathrm{mL}^{-1}$, and found significant difference $\mathrm{p}<0.05$, with a percentage of antioxidant activity higher than the standard value, used at a concentration of $200 \mu \mathrm{g} \cdot \mathrm{mL}^{-1}$ in the hexane eluate $(94.91 \%)$ and chloroform eluate $(96.11 \%)$, concentration of $150 \mu \mathrm{g} . \mathrm{mL}^{-1}$ in acetone extract $(95.93 \%)$, hexane eluate $(95.59 \%)$, chloroform eluate $(94.53 \%)$ and acetone eluate $(94.70 \%)$, whereas in the other 117 tested concentrations this same behavior was not verified, comparing the values with the commercial standard Ginkgo biloga (Egb 761), indicating the potential of this species.

The values obtained for CE50 with acetone extract of the inner bark $\left(50.44 \mu \mathrm{g} \cdot \mathrm{mL}^{-1}\right)$ and acetone eluate $(49.52$ $\left.\mu \mathrm{g} . \mathrm{mL}^{-1}\right)$ are the closest values in comparison with the values obtained with the extract of G. biloba $\left(46.62 \mu \mathrm{g} . \mathrm{mL}^{-1}\right)$, this fact is probably due to the presence of antioxidant substances, which reveals a promising antioxidant activity of the studied species. 


\section{ANTI-INFLAMMATORY ACTIVITY}

Bay-Hurtado et al. (2016) showed significant anti-edematogenic effect using the paw edema test in mice with $1 \%$ carrageenan, the acetone extract of the stem inner bark of $M$. guianensis (EAMG), hexane eluate (EHMG), chloroform eluate (EClMG), acetone eluate (EAcMG), 3 $\beta$-hydroxyfriedelane $(\mathrm{CQH}-2)$ and 3-oxo$16 \beta$-hydroxyfriedelane $(\mathrm{CQH}-3)$ of M. guianensis.

The results obtained after administering the EAMG, EHMG, ECIMG, CQH-2 and CQH-3 of M. guianensis showed that the doses, tested at the evaluated time, were effective to inhibit the formation of edema, with a higher efficacy for EAMG and $\mathrm{CQH}-3$, notably by administering CQH-3, which resulted in an inhibition of $65 \%$ in the volume of edema formation at a time of 120 minutes with a dose of $50 \mathrm{mg} / \mathrm{kg}$.

\section{Cytotoxic AND MUTAGENIC ACTIVITY}

The data show that the aqueous extract of $\mathrm{M}$. guianensis has cytotoxic effect at concentrations of 77 and $192 \mathrm{mg} / \mathrm{mL}$ ( $p<0.001$ ), (MENEGUETTI et al., 2014b; 2015). What is not worrying because these concentrations are, respectively, 20 times more concentrated than the common concentration $(3.85 \mathrm{mg} / \mathrm{ml})$ used by the population (CAMPAROTO et al., 2002).

The only treatment that showed mutagenic effect was those with $192 \mathrm{mg} / \mathrm{ml}(\mathrm{P}<0.001)(\mathrm{MENE}-$ GUETTI et al., 2014b). It was observed at this concentration some anaphasic bridges which are changes that occur because of the mutagenicity (STURBELLE et al., 2010). Thus, the study carried out by Meneguetti et al. (2014b) demonstrated, in A. cepa cells, safety regarding the cytotoxic and mutagenic effects in concentrations up to 10 times higher than those used in the traditional use of $\mathrm{M}$. guianensis. The same was also observed in mammals as it was found that aqueous extract of $\mathrm{M}$. guianensis in concentrations up to tenfold higher than the concentration used inethnopharmacology does not present genotoxic effects and, moreover, it has antigenotoxic actions in mice treated acutely (MENEGUETTI et al., 2014b).

\section{ANTIMICROBIAN ACTIVITY}

Pioneering studies such as the one performed by Lima et al. (1969) have already demonstrated that the maitenin has strong antimicrobial activity against many gram-positive bacteria. These effects were corroborated by demonstrating that extracts of leaves and roots have antimicrobial effect for several pathogens, including Staphylococcus aureus and Streptococcus sp..

Annak et al. (2009) confirmed that the gallic tannins can inhibit the growth of bacteria by changing the selective permeability of the cell wall. Tannins from the catechin have in vivo and in vitro activity against H. pylori (MABE et al., 1999). According to Singh; Dubey (2001), the friedelin and friedelan3-B-ol have in vitro antimicrobial activity against S. aureus, Escherichia coli, and also against the fungus Aspergillus niger.

\section{OTHER EFFECTS}

The triterpenes, in particular, the friedelin, have anti-inflammatory activity, reducing the edema induced in mice paws by carrageenan (SHMIZU; TOMOO, 1994). These effects may explain, in part, the analgesic action found by Gonzales et al. (2001) with the compression test of mice tail.

The friedelin and other triterpenoids of the Maytenus genus inhibit the aldose reductase enzyme; this activity is weak in isolated compounds, but consistent in triterpene fractions. This enzyme is responsible for the excess synthesis of sorbitol in diabetics, a mechanism that implicates in complications such as the peripheral neuropathy of this disease (CHAVEZ et al., 1998).

\section{CONCLUSION}

M. guianensis is an important phytotherapic in folk medicine, mainly due to its anti-inflammatory activity and general infections. Therefore, this study intends to offer support to the study on the xixuá's ethnopharmacological properties, as well as point out the benefits of its use, showing the importance of the scientific research on the various medicinal properties that this species may offer. 


\section{ACKNOWLEDGEMENTS}

The authors thanks the CNPq for financial support and the Research Support Foundation of Amazonas State (FAPEAM) for granting the scholarship.

\section{REFERENCES}

ALONSO, J.R. Tratado de fitomedicina bases clínicas y farmacológicas. Buenos Aires, Isis Ediciones SRL, 1998. p. 828-834.

ANNAN, K.; ADU, F.; GBEDEMA, SY. Friedelin: a bacterial resistance modulator from Paullinia pinnata L. Journal of Science and Technology, v.29, n.1, p.152-159, 2009.

BAY-HURTADO, F.; LIMA, R.A.; AZEVEDO, M.S.; FACUNDO, V.A. Avaliação das atividades genotóxica e antioxidante da periderme do caule de chichuá (Maytenus guianensis Klotzsch). Scientia Plena, v.11, n.7, p.1-9, 2015.

BAY-HURTADO, F.; MEDEIROS, D.S.S.; LIMA, R.A.; BAY, M.; FREITAS, E.M.F.; FACUNDO, V.A.; MEDEIROS, P.S.M. Atividade antiplasmodial e citotóxica in vitro da entrecasca do caule de Maytenus guianensis Klotzsch Ex Reissek, Revista Brasileira de Biociências, v.14, n.1, p.32-38, 2016.

BORRÁS, M.R.L. Plantas da Amazônia: medicinais ou mágicas - plantas comercializadas no Mercado Municipal Adolpho Lisboa. Manaus: Valer, 322pp. 2003.

CAMPAROTO, M.L.; TEIXEIRA, R.O.; MANTOVANI, M.S.; VICENTINI, V.E.P. Effects of Maytenus ilicifolia Mart. and Bauhinia candicans Benth infusions on onion root-tip and rat bone-marrow cells. Genetics and Molecular Biology, v.25, n.1, p.85-89, 2002.

CARLINI, E.A.; FROCHTENGARTEN, M.L. Toxicologia clínica (Fase I) da espinheira-santa (Maytenus ilicifolia). Brasília - Distrito Federal, 1988. p.67-73.

CARVALHO-OKANO, R.M.; LEITÃO-FILHO, H.F. O gênero Maytenus (Celastraceae) no Brasil extra-amazônico. In: REIS, M.S.; SILVA, S.R. Conservação e uso sustentável de plantas medicinais e aromáticas. Maytenus spp. IBAMA, Brasília, 2004.

CARVALHO-OKANO, R.M.; LEITÃO-FILHO, H.F. O gênero Maytenus Mol. emend. Mol. (Celastraceae) no Brasil extra-amazônico. In: Conservação e uso sustentável de Espinheira Santa, Volume Único, 2005. p.1151 ,

CHÁVEZ, H.; ESTÉVEZ-BRAUN, A.; RAVELO, A.G.; GONZÁLEZ, A.G. First exemples of dammarane triterpenes isolated from Celastraceae. Tetrahedron, v.53, n.18, p.6465-6472, 1998.

COIMBRA, R.; DA SILVA, E.D. Notas de Fitoterapia. Rio de Janeiro: Laboratório Clínico Silva Araújo, 1958. p.32-33.

DUARTE, L.P.; FIGUEIREDO, R.C.; DE SOUZA, G.F.; SOARES, D.B.S.; RODRIGUES, S.B.V.; SILVA, F.C.; SILVA, G.D.F. Chemical constituents of Salacia elliptica (Celastraceae). Química Nova, v.33, n.4, p.900903, 2010.

DUKE, J.A.; VÁSQUEZ, R. Amazonian ethnobotanical dictionary. CRC Press, Boca Raton, Florida, USA, 1994. $114 \mathrm{p}$.

ESTEVAM, C.S.; CAVALCANTI, A.M.; CAMBUI, E.V.F.; ARAÚJO-NETO, V.; LEOPOLDO, P.T.G.; 
FERNANDES, R.P.M.; ARAÚJO, B.S.; PORFÍRIO, Z.; SANT'ANA, A.E.G. Perfil fitoquímico e ensaio microbiológico dos extratos da entrecasca de Maytenus rigida Mart (Celastraceae). Revista Brasileira de Farmacognosia, v.19, n.1, p.299-303, 2009.

FACUNDO, V.A.; MENEGUETTI, D.U.O.; MILITÃO, J.S.L.T.; LIMA, R.A.; HURTADO, F.B.; CASSEB, A.A.; TEIXEIRA, L.F.; SILVA, I.C.; SILVA, G.V.J.; JÚNIOR-LACERDA, V. Chemical constituents from Maytenus guianensis Klotzsch ex Reissek (Celastraceae) Amazon rainforest. Biochemical Systematics and Ecology, v.58, n.1, p.270-273, 2015.

FONSECA, A.P.N.D.; SILVA, G.D.F.; CARVALHO, J.J.; SALAZAR, G.D.C.M.; DUARTE, L.P.; SILVA, R.P.; TAGLIATI, C.A.; ZANI, C.L.; NEVES, T.M.A.; PERES, V.; VIEIRA-FILHO, S.A. Estudo fitoquímico do decocto das folhas de Maytenus truncata Reissek e avaliação das atividades antinociceptiva, antiedematogênica e antiulcerogênica de extratos do decocto. Química Nova, v.30, n.4, p.842-847, 2007.

GONZALEZ, F.G.; PORTELA, T.Y.; STIPP, E.J.; DI STASI, L.C. Antiulcerogenic and analgesic effects of Maytenus aquifoliuim, Sorocea bomplandii and Zolernia ilicifolia. Journal of Ethnopharmacology, v.77, n.1, p.41-47, 2001.

GLÓRIA, B.; GUERREIRO, S. Anatomia vegetal. 2.ed. Viçosa: Editora da UFV, 2006. 438p.

HURTADO, F.B. Contribuição ao estudo fitoquímico e biológico da entrecasca da espécie Maytenus guianensis Klotzsch ex Reissek. [tese]. Universidade Federal de Rondônia: UFRO; 2013.

LIMA, O.G.; COELHO, J.S.B.; WEIGERT, E.; D'ALBUQUERQUE, I.L.; SOUZA, M.A.M. Substâncias antimicrobianas de plantas superiores. Revista do Instituto de Antibioticos, v.9, n.1, p.17-25, 1969.

LIMA, T.C.S.; MIOTO, R.C.T. Procedimentos metodológicos na construção do conhecimento científico: a pesquisa bibliográfica. Revista Katálysis, v.10, p.37-45, 2007.

LIMA, E.S.; VARGAS, F.S.; POHLIT, A.M. Antioxidant, antiinflammatory and antiplatelet aggregating activities of Maytenus guyanensis bark extract. Latin American Journal of Pharmacy, v.29, n.1, p.1107-1012, 2010.

LORENZI, H.; MATOS, F.J.A. Plantas medicinais no Brasil: nativas e exóticas. 2.ed. Nova Odessa: Plantarum, 2008.

MACEDO, S.R.A.; DE BARROS, N.B.; FERREIRA, A.S.; MENEGUETTI, D.U.O.; FACUNDO, V.A.; NICOLETE, R. Avaliação da atividade antileishmania de um triterpeno isolado de Maytenus guianensis incorporado em micropartículas biodegradáveis de PLGA. In: Congresso da Sociedade Brasileira de Medicina Tropical, 51, Anais... Fortaleza: CE, p.10, 2015.

MABE, K.; YAMADA, M.; OGUNI, I. In vitro and in vivo activities of tea catechins aigainist Helicobacter pylori. Antimicrobial Agents Chemotherapy, v.43, n.1, p.1788-1791, 1999.

MAIA, B.L.; LIMA, B.S.; VASCONCELOS, M.C. Avaliação da atividade hemolítica, coagulante e antiagregante plaquetária do extrato seco da casca de Maytenus guianensis. In: Sociedade Brasileira Para o Progresso da Ciência, 61, Anais... Manaus: AM, 2009.

MACARI, P.A.T.; PORTELA, C.N.; POHLIT, A.M. Antioxidant, cytotoxic and UVB-absorbing activity of Maytenus guianensis Klotzsch (Celastraceae) bark extracts. Acta Amazônica, v.36, n.4, p.513-518, 2006.

MENEGUETTI, D.U.O.; CUNHA, R.M.; LIMA, R.A.; OLIVEIRA, F.A.S.; MEDEIROS, D.S.S.; PASSARINI, G.M.; MEDEIROS, P.S.M.; MILITÃO, J.S.L.T.; FACUNDO, V.A. Antimalarial ethnopharmacology in the Brazilian Amazon. Revista de Ciências Farmacêuticas Básica e Aplicada, v.35, n.4, p.577-587, 2014a. 
MENEGUETTI, D.U.O.; LIMA, R.A.; PAGOTTO, R.; FACUNDO, V.A. Análise citotóxica e mutagênica do extrato aquoso de Maytenus guianensis Klozstch ex Reissek (Celastraceae) Chichuá (Xixuá) Amazônico. Ciência e Natura, v.36, n.3, p.301-309, 2014b.

MENEGUETTI, D.U.O.; LIMA, R.A.; SILVA, F.C.; PASSARINI, G.M.; FACUNDO, J.B.; PAGOTTO, R.C.; MILITÃO, J.S.L.T.; FACUNDO, V.A. Acute genotoxicity analysis in vivo of the aqueous extract of Maytenus guyanensis Amazonian chichuá. Revista Brasileira de Farmacognosia, v.25, n.2, p.164-169, 2015.

MENEGUETTI, D.U.O.; FACUNDO, V.A. Análise genotóxica e antiparasitária de extratos e substâncias isoladas de Maytenus guianensis Klotzsch ex Reissek (Celastraceae), Chichuá (Xixuá) Amazônico. Revista Pan-Amazônica de Saúde, v.6, n.4, p.69-70, 2015.

METCALFE, C.R.; CHALK, L. Anatomy of the dicotyledons: leaves, stems and wood in relation taxonomy with notes in economic uses. 2.ed. Oxford: Clarendon Press, 1957. 397p.

MOHAMED, F.A.; PERWEZ, A. Anti-inflammatory activity and qualitative analyses of different extracts of Maytenus obscura (RICH) by high performance thin layer chromatography method. Asian Pac Journal Tropical Biomedical, v.4, n.2, p.152-157, 2014.

NEGRI, M.L.S.; POSSAMAI, J.C.; NAKASHIMA, T. Atividade antioxidante das folhas de espinheira-santa - Maytenus ilicifolia Mart. ex Reiss., secas em diferentes temperaturas. Revista Brasileira de Farmacognosia, v.19, n.2, p.553-556, 2009.

OLIVEIRA, C.R.; SEVER, M.A.C.; DE MORAES, M.O.; DE MELO, L.V.; GOMES, A.P.; SILVA, R.L.; DOS SANTOS, M.L. Avaliação citotóxica em três linhagens de células tumorais das frações obtidas da casca do caule de Salacia crassifolia (MART). Revista Ciência Química e Farmácia, v.41, n.2, p.133-142, 2012.

OSAKADA, A. Desenvolvimento inicial de sangue-de-dragão (Croton lechleri MULL. ARG) sob diferentes classes de solos, corretivos e níveis de luminosidade da Amazônia Central. [dissertação]. Instituto Nacional de Pesquisas da Amazônia: INPA; 2009.

PINHEIRO, J.A. Análise da Constituição Química da Madeira de Maytenus guianensis Klotzch. [dissertação]. Universidade Federal de Minas Gerais: UFMG; 1990.

PRATA, R.R. Aspectos anatômicos e etnofarmacológicos do caule e raiz de Maytenus guyanensis Klotzsch ex Reissek (Celastraceae). [dissertação]. Instituto Nacional de Pesquisas da Amazônia: INPA; 2007.

REVILLA, J. Apontamentos para a cosmética Amazônica. SEBRAE-INPA, Manaus, Amazonas, 2002. 445p.

RIBEIRO, A.Q.; MOURA, C.S. Informações sobre plantas medicinais e fitoterápicos no contexto da farmacoterapia. In: Fitoterapia: bases científicas e tecnológicas, 328p. 2009.

RODRIGUES, W.C. Metodologia Científica. FAETEC/IST. Paracambi, 2007.

SANTOS-OLIVEIRA, R.; COULAND-CUNHA, S.; COLACO, W. Revisão da Maytenus ilicifolia Mart., Celastraceae. Contribuição ao estudo das propriedades farmacológicas. Revista Brasileira de Farmacognosia, v. 19, n.2, p.650-659, 2009.

SHIMIZU, M.; TOMOO, T. Anti-inflammatory constituents of topicaly applied drugs V: constituents with anti-inflammatory from Aoki (Aukuba japonica Thumb.). Biological Pharmaceutical Bulletin, v.17, n.1, p.665-667, 1994.

SIMÕES, C.M.O.; SCHENKEL, E.P.; GOSMANN, G.; MELLO, J.C.P.; MENTZ, L.A.; PETROVICK, P.R. Farmacognosia: da planta ao medicamento. 6.ed. 1002p. Porto Alegre/Florianópolis: Editora da UFSC/ Editora da UFRGS. 2007. 
SINGH, B.; DUBEY, M.M. Estimation of triterpenoids from Heliotropium maifolium Kohen ex Retz in vivo and in vitro: antimicrobial screening. Phytotherapy Research, v.15, n.1, p.231-234 2001.

SPIVEY, A.C.; WESTON, M.; WOODHEAD, S. Celastraceae sesquiterpenoids: biological activity and synthesis. Chemical Society Review, v.31, n.1, p.43-49, 2002.

SOLEREDER, H. Systematic anatomy of the dicotyledons II. Oxford: Clarendon Press, 1908. p.874-880.

SOUSA, J.R.; PINHEIRO, J.A.; RIBEIRO, E.F.; SOUZA, E.; MAIA, G.S. A sesquiterpene evoninoate alkaloid from Maytenus guianensis. Phytochemistry, v.25, n.7, p.1776-1778, 1986.

STURBELLE, R.; PINHO, D.S.; RESTANI, R.G.; OLIVEIRA, G.R.; GARCIAS, G.L.; MARTINHO-ROTH, M.G. Avaliação da atividade mutagênica e antimutagênica da Aloe vera em teste de Allium cepa e teste de micronúcleo em linfócitos humanos binucleados. Revista Brasileira de Farmacognosia, v.20, n.3, p.409-415, 2010.

TOZONI-REIS, M.F.C. A pesquisa e a produção de conhecimentos. In: PINHO, S.Z. (Org.). Cadernos de Formação: Formação de Professores. Educação, Cultura e Desenvolvimento. Volume 3. São Paulo: Cultura Acadêmica. v.3, p. 111-148, 2010. 